\title{
Neural Agrin Induces Ectopic Postsynaptic Specializations in Innervated Muscle Fibers
}

\author{
Thomas Meier, ${ }^{1}$ Dominik M. Hauser, ${ }^{3}$ Matthias Chiquet, ${ }^{4}$ Lukas Landmann,, ${ }^{2}$ Markus A. Ruegg, ${ }^{3}$ and \\ Hans R. Brenner ${ }^{1}$ \\ Institutes of ${ }^{1}$ Physiology and ${ }^{2}$ Anatomy and ${ }^{3}$ Biozentrum, University of Basel, $\mathrm{CH}-4051$ Basel, Switzerland, and ${ }^{4} \mathrm{Maurice}$ \\ E. Müller Institute for Biomechanics, University of Berne, CH-3010 Berne, Switzerland
}

Neural agrin, in the absence of a nerve terminal, can induce the activity-resistant expression of acetylcholine receptor (AChR) subunit genes and the clustering of synapse-specific adult-type AChR channels in nonsynaptic regions of adult skeletal muscle fibers. Here we show that, when expression plasmids for neural agrin are injected into the extrasynaptic region of innervated muscle fibers, the following components of the postsynaptic apparatus are aggregated and colocalized with ectopic agrininduced AChR clusters: laminin- $\beta 2$, MuSK, phosphotyrosinecontaining proteins, $\beta$-dystroglycan, utrophin, and rapsyn. These components have been implicated to play a role in the differentiation of neuromuscular junctions. Furthermore, ErbB2 and ErbB3, which are thought to be involved in the regulation of neurally induced AChR subunit gene expression, were colocal- ized with agrin-induced AChR aggregates at ectopic nerve-free sites. The postsynaptic muscle membrane also contained a high concentration of voltage-gated $\mathrm{Na}^{+}$channels as well as deep, basal lamina-containing invaginations comparable to the secondary synaptic folds of normal endplates. The ability to induce AChR aggregation in vivo was not observed in experiments with a muscle-specific agrin isoform. Thus, a motor neuron-specific agrin isoform is sufficient to induce a full ectopic postsynaptic apparatus in muscle fibers kept electrically active at their original endplate sites.

Key words: neuromuscular junction; MuSK; utrophin; rapsyn; laminin- $\beta 2$; agrin $\beta$-dystroglycan; ErbB receptor; acetylcholine receptor; sodium channel
During the development of the neuromuscular junction (NMJ) a small region of the skeletal muscle fiber differentiates under the control of the motor neuron to form a postsynaptic apparatus. This structure is highly specialized in morphology and molecular composition and is thought to serve the stable aggregation of a high density of acetylcholine receptors (AChRs) in the synaptic muscle membrane (Fallon and Hall, 1994; Apel and Merlie, 1995; Carbonetto and Lindenbaum, 1995) and to induce the synthesis of a synapse-specific AChR subtype containing an $\epsilon$-subunit (Brenner at al., 1990; Sanes et al., 1991).

Proteins of the postsynaptic apparatus implicated in the aggregation of AChRs include utrophin, a synapse-specific homolog of dystrophin (Ohlendieck et al., 1991; Bewick et al., 1992; Tinsley et al., 1992, 1994), $\alpha$ - and $\beta$-dystroglycan (Ibraghimov-Beskrovnaya et al., 1992; Fallon and Hall, 1994), and rapsyn (Frail et al., 1988; Apel et al., 1995), thought to link AChRs to the cytoskeleton. Several lines of evidence indicate that the redistribution of AChRs to form postsynaptic aggregates is triggered by the protein agrin, a component of the synaptic basal lamina (BL; McMahan, 1990). Consistent with this hypothesis, bath-applied agrin induces in cultured myotubes the accumulation of AChRs and other molecules associated with normal NMJs (Wallace,

Received April 29, 1997; revised June 9, 1997; accepted June 11, 1997.

This work was supported by grants from the Swiss National Science Foundation and from the Swiss Foundation for Research on Muscle Diseases to H.R.B. and M.A.R. We thank Dr. S. Froehner for anti-rapsyn mAb 1234 and Dr. R. Levinson for anti-Na ${ }^{+}$channel antiserum. The excellent technical assistance by Ms. M. Lichtsteiner, V. Gaschen (Berne), and Mr. B. Schumacher is gratefully acknowledged. We also thank Dr. B. Hunziker (Berne) for providing EM facilities and G. Jones for comments on this manuscript.

Correspondence should be addressed to Dr. Hans Rudolf Brenner, Department of Physiology, University of Basel, Vesalgasse 1, CH-4051 Basel, Switzerland.

Copyright (C) 1997 Society for Neuroscience $0270-6474 / 97 / 176534-11 \$ 05.00 / 0$
1989), and, in mice carrying a mutated agrin gene, muscle fibers fail to form functional endplates (Gautam et al., 1996). Agrin is characterized by alternatively spliced sites, termed A and B (y and $\mathrm{z}$ in rat agrin; Rupp et al., 1992) at the C-terminal end and, in the chick, the NtA domain at the N-terminal part (Ruegg et al., 1992; Denzer et al., 1995). In vitro, the most potent AChRaggregating isoform of agrin is expressed by motor neurons and contains a four amino acid insert at the A splice site and an eight amino acid insert at the B splice site. In contrast, little or no AChR-aggregating activity is observed with the agrin isoform that lacks inserts at sites A and B and is expressed predominantly by non-neuronal cells, including muscle (for review, see Bowe and Fallon, 1995).

The AChR-aggregating function of agrin requires the synapsespecific receptor tyrosine kinase MuSK, which is tyrosinephosphorylated by agrin isoforms active in AChR aggregation (Valenzuela et al., 1995; DeChiara et al., 1996; Glass et al., 1996). Similarly, phosphorylation of the AChR $\beta$-subunit seems to be required for agrin-induced AChR aggregation (Wallace et al., 1991; Meier et al., 1995, 1996).

The synthesis of adult AChRs at the synapse in electrically active muscle is maintained by a factor that also is bound to the synaptic BL (Brenner et al., 1992; Jo and Burden, 1992; Herczeg et al., 1995). By inducing ectopic secretion of neural agrin from muscle fibers in vitro and in vivo, we have shown recently that neural agrin, immobilized presumably by attachment to the extracellular matrix, is sufficient to induce ectopic adult-type AChR aggregates (Jones et al., 1996, 1997). Given the functional similarities of ectopic agrin-induced AChR clusters to AChRs at normal mature endplate membrane, we now show that the neural agrin isoform cAgrin ${ }_{7 \mathrm{~A} 4 \mathrm{~B} 8}$ (Denzer et al., 1995) also induces the 
localized expression of structural components characteristic of a normal postsynaptic apparatus. In contrast, cAgrin ${ }_{7 \mathrm{AOB} 0}$, an isoform lacking AChR-aggregating activity on cultured myotubes, failed to induce ectopic AChR aggregates in vivo. We propose that neural agrin alone is sufficient to induce all aspects of functional and structural postsynaptic differentiation in vivo and that this activity is restricted to agrin isoforms that normally are expressed by motor neurons.

\section{MATERIALS AND METHODS}

Agrin plasmids and muscle fiber injections. Full-length chick agrin constructs $\mathrm{cAgrin}_{7 \mathrm{~A} 4 \mathrm{~B} 8}$ and cAgrin ${ }_{7 \mathrm{A0B} 0}$ (Denzer et al., 1995) and green fluorescence protein (GFP) were cloned into pcDNAI (Invitrogen, San Diego, CA), dissolved at $200 \mathrm{ng} / \mu \mathrm{l}$ in $150 \mathrm{~mm} \mathrm{KCl}$ containing Fast Green FCF ( $25 \mathrm{mg} / \mathrm{ml}$; Sigma, St. Louis, MO), back-filled into micropipettes, and pressure-injected under electrophysiological control into to the proximal endplate-free region of single soleus muscle fibers in rats anesthetized with Nembutal $(1 \mathrm{ml} / \mathrm{kg})$ (Jones et al., 1997). After the surgical cut was closed, animals were kept for 7 weeks. Injected soleus muscles remained innervated during the entire period. For analysis, excised soleus muscles were stained for AChR with rhodamine- $\alpha$-bungarotoxin (Rh- $\alpha$ BGT; Molecular Probes, Eugene, OR) or for agrin with a polyclonal anti-chicken agrin antiserum (Gesemann et al., 1995) and BODIPY-conjugated goat anti-rabbit IgG (Molecular Probes). In some experiments the sciatic nerve was cut, and the soleus muscle was removed after $4 \mathrm{~d}$. To obtain regenerated muscle preparations, we injected denervated rat soleus muscle with Notexin, and their endplate region was frozen 2 d later (Brenner et al., 1992). Unstimulated muscles were allowed to regenerate for $20 \mathrm{~d}$. For analysis, all muscles were quickfrozen in prechilled isopentane and cryocut into $12 \mu \mathrm{m}$ sections.

Immunohistochemistry and antibodies. Unfixed sections were rinsed briefly with PBS and preincubated for 5-10 min in PBS supplemented with $5 \%$ horse serum, $1 \%$ bovine serum albumin, and $0.1 \%$ Triton $\mathrm{X}-100$. The following primary antibodies were diluted in 5\% horse serum, $1 \%$ bovine serum albumin, and $0.01 \%$ Triton X-100 in PBS, as indicated in the references or data sheets, and sections were incubated for $2 \mathrm{hr}$ at room temperature: anti-chick agrin (Reist et al., 1987), monoclonal antibody (mAb) 5B1; anti-rat agrin (Hoch et al., 1994), mAb AGR-435 (StressGen number 550); anti-laminin- $\beta 2$ (Sanes et al., 1990), mAb C4; anti $\beta$-dystroglycan (Bewick et al., 1992), mAb 8D5 (NovoCastra, Newcastle, UK); anti-utrophin (Bewick et al., 1992), mAb DRP1/12B6 (NovoCastra); anti-rapsyn (Froehner, 1984), mAb 1234; anti-phosphotyrosine, mAb 4G10 (Upstate Biotechnology); anti-ErbB2/Neu, Ab C-18 (Santa Cruz Biotechnology, Dr. Glaser AG, Switzerland); and antiErbB3, Ab C-17 (Santa Cruz Biotechnology); and anti-sodium channel (Dugandzija-Novakovic et al., 1995), polyclonal serum (Upstate Biotechnology, Lake Placid, NY). As control, anti-Na ${ }^{+}$channel antibodies were preabsorbed with the peptide antigen as described (DugandzijaNovakovic et al., 1995). For detection, FITC-labeled goat anti-mouse or goat anti-rabbit IgG (Jackson ImmunoResearch, West Grove, PA) was used. For triple staining, sections were photographed for Rh- $\alpha$ BGT labeling and reincubated with anti-chick agrin $\mathrm{mAb} 5 \mathrm{~B} 1$, followed by Cy3-conjugated secondary antibody (Molecular Probes). This labeling was very intense and required an $\sim 10$ times shorter exposure time for documentation than the Rh- $\alpha$ BGT signal. To increase the sensitivity for the detection of ErbB2 and ErbB3 primary antibodies, we used unconjugated goat anti-rabbit IgG (Cappel, Cochranville, PA), followed by FITC-conjugated rabbit anti-goat IgG (Jackson ImmunoResearch). Immunofluorescence micrographs were taken on a Zeiss Axiophot microscope (Oberkochen, Germany) equipped with appropriate fluorescence filter sets.

Expression construct encoding the extracellular domain of Nsk2, the mouse homolog to MuSK. PCR was conducted according to the manufacturer's advice with Pwo-polymerase (Boehringer Mannheim, Mannheim, Germany). To distinguish expression constructs and recombinant protein, cDNA constructs are named with the prefix $p$, followed by the name of the recombinant protein they encode. PCR reactions were conducted on partial cDNA clones (provided by Dr. A. D. Reith, Ludwig Institute for Cancer Research, London, UK) encoding the extracellular domain of Nsk2 (Ganju et al., 1995). PCR products were ligated into pcDNAI (Invitrogen) containing a tag consisting of the constant region of mouse immunoglobulin $(\mathrm{Fc})$, which was generated by restriction digestion of $p \mathrm{cN} 25_{7} \mathrm{Fc}$ (Denzer et al., 1997) with EcoRI and BamHI. The resulting construct, $p$ Nsk2Fc, was digested with EcoRI and $X b a \mathrm{I}$ restriction endonucleases and ligated into EcoRI/XbaI cut $p c \mathrm{I}^{\mathrm{NEO}}$ expression vector (Promega, Madison, WI), giving rise to $p I^{\mathrm{N}} \mathrm{Nsk} 2 \mathrm{Fc}$. All PCR products used to generate expression constructs were sequenced to ensure that no mutations were introduced by DNA amplification.

Culturing and transfection of COS-7 and human embryonic kidney (HEK) 293 cells. COS-7 (Gluzman, 1981) cells were cultured in DMEM (Life Technologies, Gaithersburg, MD) supplemented with $10 \%$ newborn calf serum, $10 \mathrm{~mm}$ sodium pyruvate, $100 \mathrm{U} / \mathrm{ml}$ penicillin, and 100 $\mu \mathrm{g} / \mathrm{ml}$ streptomycin. COS-7 cells were transiently transfected with $p$ Nsk2Fc, using the DEAE-dextran-based method (Cullen, 1987). HEK 293 cells were cultured in the same medium as described above and stably transfected with $p I^{\mathrm{N}} \mathrm{Nsk} 2 \mathrm{Fc}$ according to Gorman et al. (1990). Stably transfected HEK 293 cells were selected with G418 $(800 \mu \mathrm{g} / \mathrm{ml})$, and surviving colonies were picked and stained intracellularly with FITCconjugated goat anti-mouse IgG (Jackson ImmunoResearch). Colonies expressing high levels of recombinant $\mathrm{Nsk} 2 \mathrm{Fc}$ were cloned subsequently by limited dilution.

Purification of recombinant Nsk2Fc. Transiently transfected COS-7 cells or stably transfected HEK 293 cells were grown in medium, as described above, in which the newborn calf serum was replaced by IgG-depleted fetal calf serum (Life Technologies). Supernatants usually were collected 3-6 d after transfection, and the conditioned medium was incubated with protein A-Sepharose (Pharmacia). The Sepharose beads were washed with 25 vol of $0.1 \mathrm{M}$ sodium phosphate, $\mathrm{pH}$ 7.5. Columnbound proteins were eluted with $10 \mathrm{vol}$ of $0.1 \mathrm{~m}$ glycine, $\mathrm{pH} 3.5$. Fractions of $1.5 \mathrm{ml}$ were collected and buffered immediately with $35 \mu \mathrm{l}$ of $1 \mathrm{M}$ Tris- $\mathrm{HCl}, \mathrm{pH}$ 8.0. Aliquots of each fraction were analyzed on $10 \%$ SDS-PAGE, and proteins were visualized by silver staining (Morrisey, 1981). Fractions with high concentrations of Nsk2Fc were pooled and dialyzed three times against 1.51 of PBS. Fractions with low concentration of Nsk2Fc were concentrated with the Centriplus concentrator (Amicon, Beverly, MA). Nsk2Fc concentration was determined according to Lowry et al. (1951) with the DC Protein assay kit (Bio-Rad Laboratories, Glattbrugg, Switzerland) and BSA as a standard. Furthermore, the relative intensity of Nsk2Fc and of known amounts of BSA was compared on silver-stained gels as an independent measure.

Anti-Nsk2 extracellular domain sera (anti-Nsk2Fc). Polyclonal antisera were raised in rabbits by injecting protein A-Sepharose-purified Nsk2Fc. For the first injection $70 \mu \mathrm{g}$ of protein in complete Freund's adjuvant was used. For booster injections in 4-8 wk intervals, the same amount of Nsk2Fc was dissolved in incomplete Freund's adjuvant. This antiserum is referred to as anti-MuSK/Nsk2 to indicate the homology of MuSK cloned from Torpedo, human, rat, and chicken (Jennings et al., 1993; Valenzuela et al., 1995; DeChiara et al., 1996; Glass et al., 1996) with Nsk2 cloned in mouse (Ganju et al., 1995).

Electron microscopy. Plasmid-injected muscle was excised and fixed with $2.5 \%$ glutaraldehyde in $0.1 \mathrm{M}$ sodium cacodylate buffer, $\mathrm{pH} 7.4$, for $24 \mathrm{hr}$. Fixed muscle was stained for acetylcholinesterase (AChE) activity according to Koelle and Friedenwald (1949). Normal endplates as well as stained regions induced by ectopic agrin expression were identified under a dissecting microscope. Pieces of tissue $\left(1-3 \mathrm{~mm}^{3}\right)$ were cut from these areas and post-fixed overnight with $2 \%$ osmium tetroxide in $0.1 \mathrm{~m}$ sodium cacodylate buffer, $\mathrm{pH}$ 7.4. Tissue blocs were dehydrated with ethanol and propylene oxide and embedded in Epon; $1-\mu \mathrm{m}$-thick longitudinal sections were prepared. Semithin sections were counterstained with toluidine blue and inspected for AChE staining. Then ultrathin sections were prepared from positive areas, stained with uranylacetate and lead citrate, and viewed in a Hitachi 7100 electron microscope.

\section{RESULTS}

Rat muscle fibers were induced to express the neural chicken

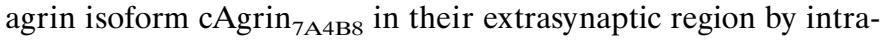
cellular injection of expression plasmids (Jones et al., 1997). In culture, recombinant cAgrin ${ }_{7 \mathrm{~A} 4 \mathrm{~B} 8}$ is capable of inducing $\mathrm{AChR}$ aggregates, and it binds to the BL component laminin (Denzer et al., 1997). On its secretion from the injected fibers, such agrin presumably became attached to extracellular matrix. Each site secreting agrin was associated, both in the injected as well as in adjacent fibers, with ectopic nerve-free clusters of AChRs. We have shown previously that they contain synapse-specific adulttype AChR channels (Jones et al., 1997). Close inspection of agrin-expressing sites showed that agrin immunoreactivity on the 
fiber surface extended over a distance of approximately three to five fiber diameters. Within the agrin-positive regions, smaller but stronger deposits of agrin often were seen that closely matched AChR clusters (see, for example, Fig. $8 A$ ). Thus, although AChR clusters were always associated with agrin-secreting sites, they did not extend over the entire length of the deposit. As with normal endplates, the agrin-induced ectopic AChR clusters were resistant to electrical muscle activity, because the fibers were innervated during the entire time of the experiment, i.e., up to 7 weeks. AChR clusters were absent from the noninjected regions distant from the injection sites (data not shown).

To investigate whether cAgrin $_{7 \mathrm{~A} 4 \mathrm{~B} 8}$ is sufficient to induce a postsynaptic apparatus that is also structurally similar to that of normal endplates, we have conducted a detailed study on the molecules assembled at ectopic agrin-induced AChR clusters. To this end, sites of $\mathrm{CAgrin}_{7 \mathrm{~A} 4 \mathrm{~B} 8}$ expression in rat soleus muscle were localized by staining the entire muscle with rhodamine-labeled $\alpha$-bungarotoxin (Rh- $\alpha$ BGT). Sections subsequently were stained for chick agrin and the endogenous rat agrin. As shown in Figure $1 A$, cAgrin 7 A488 was not confined to the surface of the injected fiber but was associated also with adjacent fibers, and at such deposits AChR aggregates were found (Fig. $1 B$; see also Fig. $8 A, B)$. However, agrin deposits extended further along the fiber circumferences than did AChR clusters. The anti-chick agrin antibodies did not cross-react with rat agrin present at the original, normal endplates of the muscle (Fig. 1C,D). Conversely, the mAb 435 (Hoch et al., 1994), while staining rat agrin at original endplates (Fig. 1G,H), did not stain ectopic chick agrin deposits (Fig. $1 E, F$ ). These results suggest that AChR aggregation at ectopic sites in adult muscle fibers is not accompanied by a significant accumulation of muscle (rat) agrin.

\section{Ectopic agrin induces accumulation of several synaptic proteins}

Normal endplates are characterized by the accumulation of specific molecules in the postsynaptic apparatus of the muscle fiber. In synaptic $\mathrm{BL}$, these components include, in addition to agrin and $\mathrm{AChE}$, a laminin isoform containing the $\beta 2$ chain (Hunter et al., 1989; Sanes et al., 1990). We have shown previously that AChE activity is tightly colocalized with agrin-induced ectopic AChR clusters (Jones et al., 1997). Full-length cAgrin ${ }_{7 \mathrm{~A} 4 \mathrm{~B} 8}$ binds to laminin- $\beta 2$ (Denzer et al., 1997) and to $\alpha$-dystroglycan (Bowe et al., 1994; Campanelli et al., 1994; Gee et al., 1994; Sugiyama et al., 1994; Gesemann et al., 1996). We therefore asked whether $\operatorname{cAgrin}_{7 \mathrm{~A} 4 \mathrm{~B} 8}$ would induce accumulation of laminin- $\beta 2$ or dystroglycans at ectopic AChR aggregates. As shown in Figure 2, laminin- $\beta 2$ clearly was enriched at ectopic AChR clusters. Similarly, $\beta$-dystroglycan, which originates from the same precursor protein as $\alpha$-dystroglycan and remains strongly associated with it (for review, see Henry and Campbell, 1996), and the cytoplasmic NMJ-specific utrophin also were colocalized at AChR aggregates (Fig. 2). As with normal endplates (data not shown), the distribution of laminin- $\beta 2$ and utrophin was confined almost entirely to AChR aggregates, whereas $\beta$-dystroglycan merely was enriched at such sites. The ectopic AChR clusters were also positive for the binding sites recognized by the lectin Vicia villosa-B4 agglutinin (VVA-B4; data not shown). Such $N$-acetylgalactosaminylterminated saccharides have been proposed to play a role in agrin-mediated AChR clustering (Martin and Sanes, 1995).

Agrin-induced tyrosine phosphorylation of AChRs and their interaction with rapsyn reduce their lateral mobility and seem to be required for agrin-induced receptor aggregation. To see
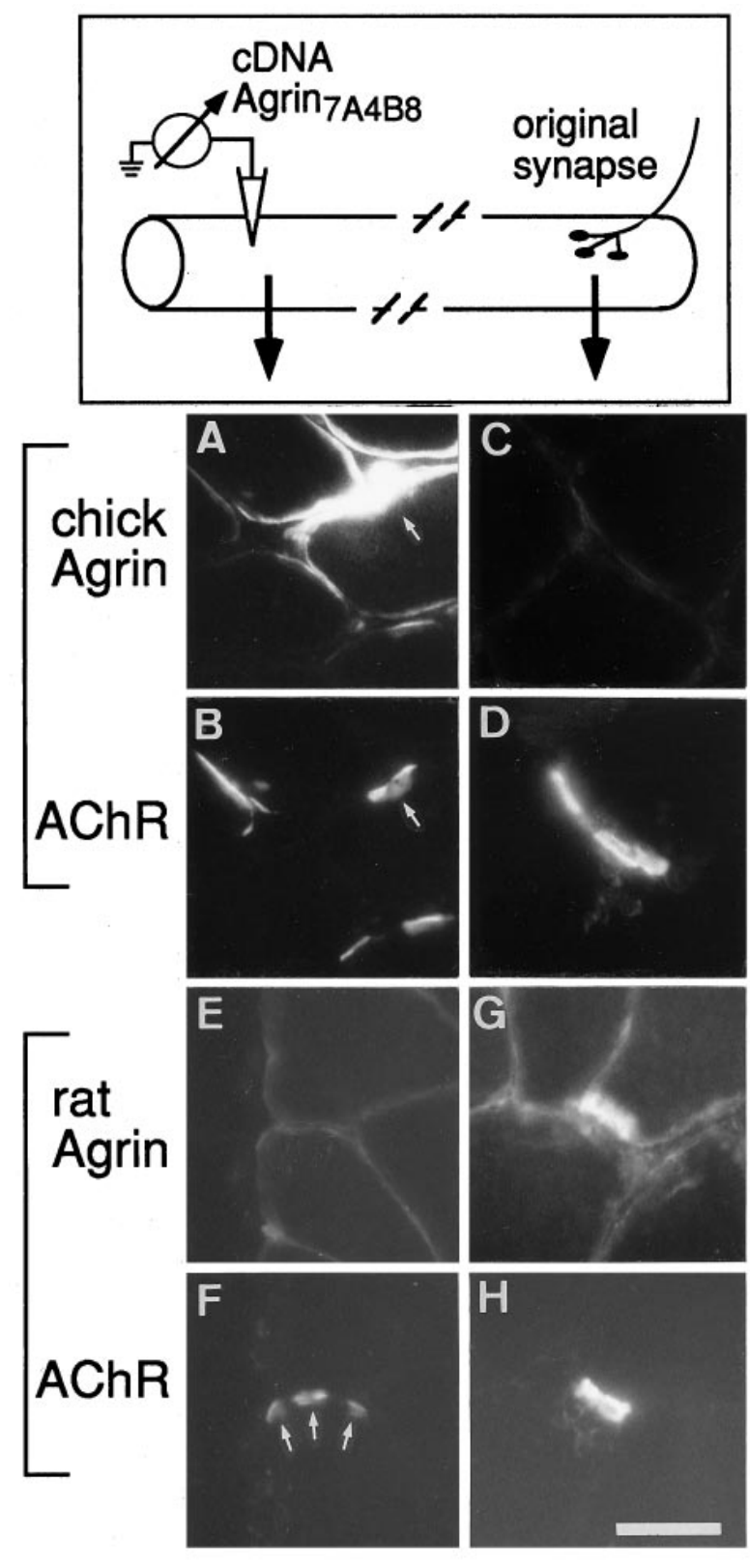

Figure 1. Intracellular injection of cDNA constructs encoding neural chick agrin into the endplate-free region of rat soleus muscle induces the aggregation of AChRs, but not of (muscle) rat agrin. Individual muscle fibers were injected with an expression plasmid encoding cAgrin $_{7 \mathrm{~A} 4 \mathrm{~B} 8}$ at extrasynaptic regions (top). Analysis of sections from ectopic sites revealed that regions expressing chick agrin $(A)$ contained ectopic AChR aggregates $(B)$. Note that there is no obvious correlation between the amount of expressed chick agrin and aggregated AChRs, because both regions with strong chick agrin expression (arrows) as well as regions with much weaker agrin expression, possibly at neighboring fibers, induced the accumulation of AChRs. Antibodies raised against chick agrin did not cross-react with rat agrin, because original endplates were not stained $(C$, $D$ ). With the use of a monoclonal antibody specific for rat agrin (Hoch et al., 1994), endogenous muscle agrin was not detected at AChR-positive sites induced by ectopic chick agrin $(E, F)$. The same antibody, however, stained rat agrin at original endplates $(G, H)$. Scale bar, $35 \mu \mathrm{m}$.

whether the agrin-induced aggregation of AChRs at ectopic sites might follow a similar mechanism, we double-stained Rh- $\alpha$ BGTlabeled ectopic receptors with antibodies for rapsyn and phosphotyrosine (Fig. 3). As with normal endplates, AChR aggregates 


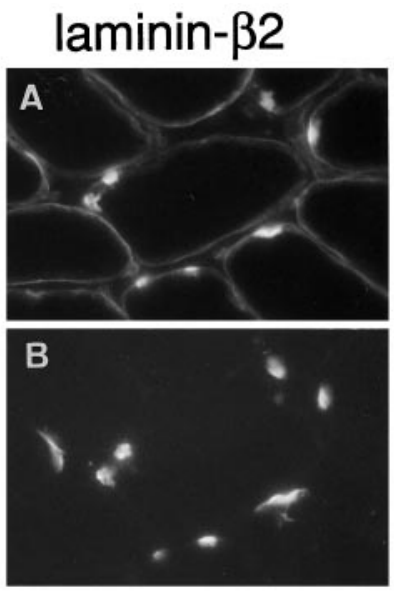

AChR
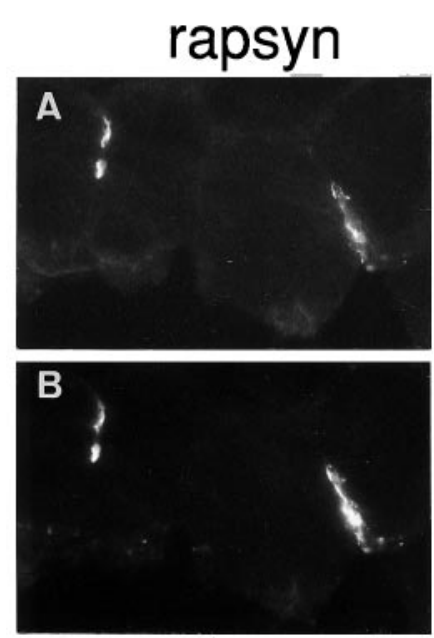

$\mathrm{AChR}$ $\beta$-dystroglycan

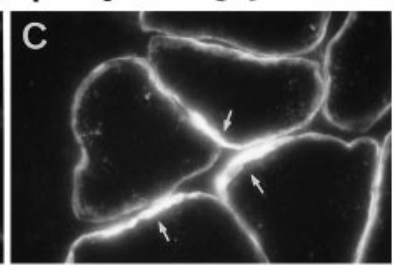

D

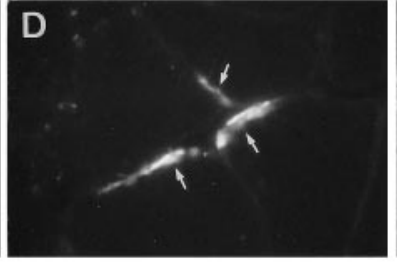

AChR
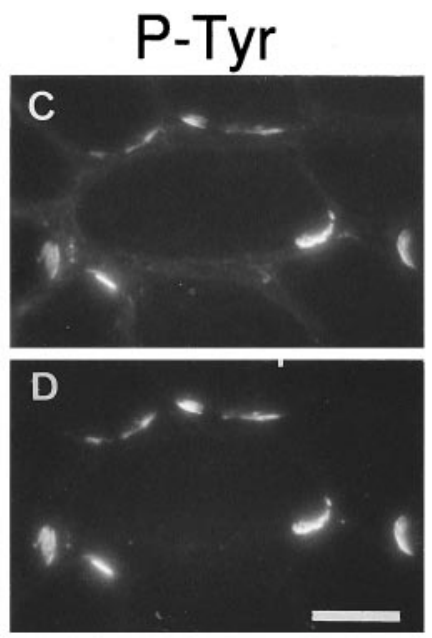

$\mathrm{AChR}$

Figure 3. Colocalization of rapsyn and phosphotyrosine with AChR aggregates induced by ectopic neural chick agrin. Staining for rapsyn $(A)$ and phosphotyrosine-containing proteins $(P-T y r ; C)$ is colocalized with ectopic AChR aggregates $(B, D)$. Scale bar, $35 \mu \mathrm{m}$.

induced by extrasynaptically expressed agrin also stained for rapsyn and tyrosine-phosphorylated proteins. Thus, secretion of cAgrin $_{7 \mathrm{~A} 4 \mathrm{~B} 8}$ from innervated muscle fibers at ectopic sites is sufficient to induce the colocalized accumulation of specific components at three different levels of normal endplates: muscle BL, membrane, and cytoplasm.

\section{The receptor tyrosine kinase MuSK colocalizes with cAgrin $_{\text {7A4B8 }}$}

The muscle-specific receptor tyrosine kinase, MuSK, is required for the formation of the NMJ. Several lines of evidence indicate that MuSK is part of a signal-transducing receptor complex activated by agrin (Glass et al., 1996). In innervated muscle MuSK is concentrated at synapses, whereas after denervation it is expressed along the entire length of the muscle fiber (Valenzuela et al., 1995). To study the distribution of MuSK in injected rat muscle, we generated a polyclonal serum specific for the extracellular domains of Nsk2, the mouse homolog of MuSK. This antiserum recognized Nsk2 in cultured $\mathrm{C} 2 \mathrm{C} 12$ myotubes (data utrophin

Figure 2. Expression of chick neural agrin in extrasynaptic regions causes the accumulation of synapse-specific components of the extracellular matrix and the dystrophin-associated glycoprotein complex in muscle membrane. Staining for laminin- $\beta 2(A)$ and utrophin $(E)$ are colocalized with ectopic AChR aggregates $(B, F)$. In contrast, $\beta$-dystroglycan $(C$, arrows $)$ is present throughout the myofiber circumference but is increased at ectopic AChR aggregates $(D, a r-$ rows). The distribution of all three molecules with respect to AChR clusters is similar to that of original nerve-induced endplates. Scale bar, $35 \mu \mathrm{m}$.
AChR not shown), and it stained normal rat endplates (Fig. 4A,B). No staining was observed with the preimmune serum (Fig. $4 C, D$ ) or the secondary antibody alone (data not shown). Expression of cAgrin $_{\text {7A4B8 }}$ in extrasynaptic regions clearly induced MuSK/Nsk2 protein. All of the ectopic AChR clusters were also MuSK/Nsk2positive (data not shown), but like ectopic cAgrin ${ }_{7 \mathrm{~A} 4 \mathrm{~B} 8}, \mathrm{MuSK} /$ Nsk2 protein also could be resolved in fiber regions adjacent to the agrin-induced AChR clusters (Fig. 4E,F). In fact, re-staining sections with anti-chick agrin antibodies showed that MuSK/Nsk2 protein was well colocalized with anti-chick agrin immunoreactivity (Fig. $4 G-I, J-L$ ). Thus, the colocalization of MuSK/Nsk2 and agrin is not sufficient to induce the accumulation of AChRs along the entire length of ectopic agrin deposits.

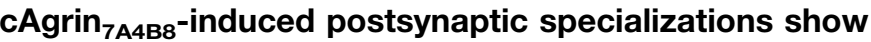 signs of maturation}

Maturation of the neuromuscular synapse is characterized by the accumulation of voltage-gated $\mathrm{Na}^{+}$channels, the aggregation of myonuclei that selectively transcribe AChR genes, and the generation of postsynaptic folds. Earlier work has shown that some aspects of synapse maturation are found at $\mathrm{cAgrin}_{7 \mathrm{~A} 4 \mathrm{~B} 8}$-induced ectopic sites (Jones et al., 1997). To complete these studies, we now have examined, using an anti-peptide antiserum, the distribution of voltage-gated $\mathrm{Na}^{+}$channels and the formation of membrane infoldings at agrin-induced ectopic AChR clusters. Accumulation of $\mathrm{Na}^{+}$channel labeling was seen at ectopic cAgrin ${ }_{7 \mathrm{~A} 4 \mathrm{~B} 8}$-expressing sites, and it also colocalized with ectopic AChR aggregates (Fig. $5 E, F)$. At some sites, however, accumulations of $\mathrm{Na}^{+}$channels extended beyond AChR clusters (Fig. $5 G-I$ ).

The ultrastructure of muscle fibers at ectopic agrin-induced AChR clusters was examined in the electron microscope. Marking such sites histochemically for AChE activity enabled us to localize them readily in thin sections. AChE-stained sections, indeed, contained deep sarcolemmal invaginations that contained BL comparable to those at normal endplates (Fig. 6). Such invaginations were associated with numerous mitochondria and morphologically distinct nuclei.

\section{Aggregation of ErbB receptors}

At normal synapses AChR subunit gene transcription in the subsynaptic nuclei of the muscle fiber is thought to be induced by neuregulin-mediated phosphorylation of members of the ErbB family of receptor tyrosine kinases (Martinou et al., 1991; Falls et 
endplate

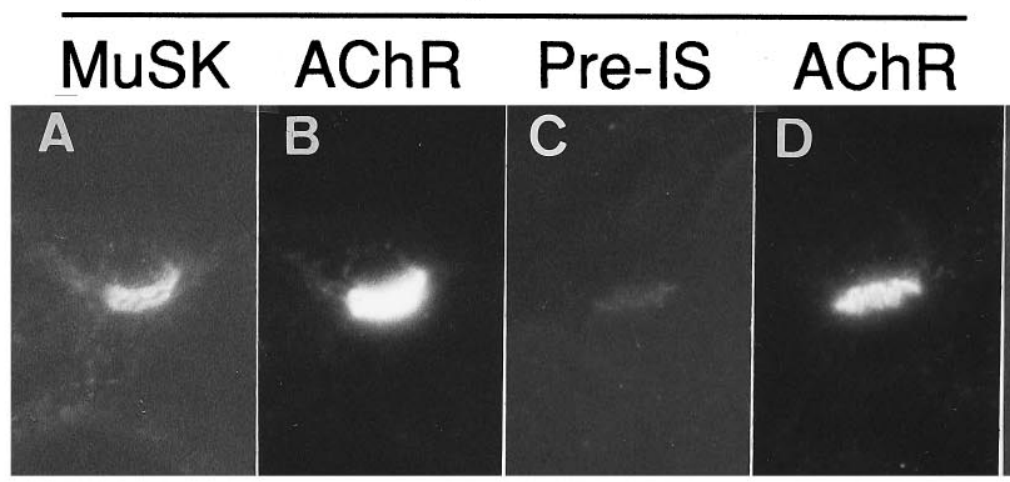

ectopic Agrin

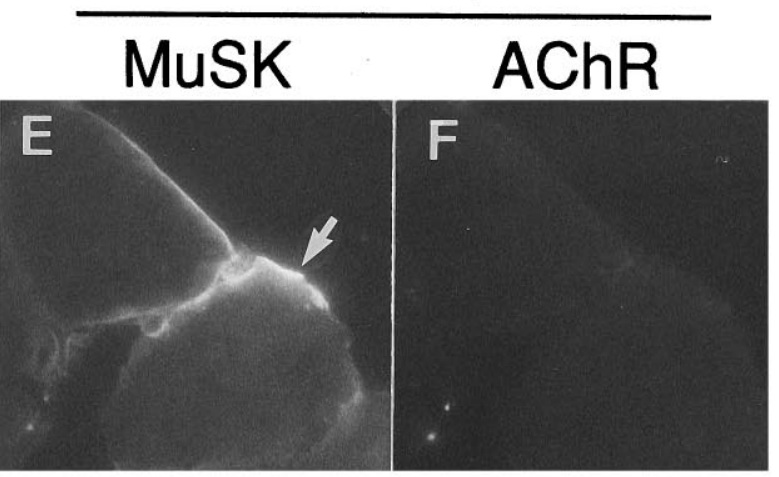

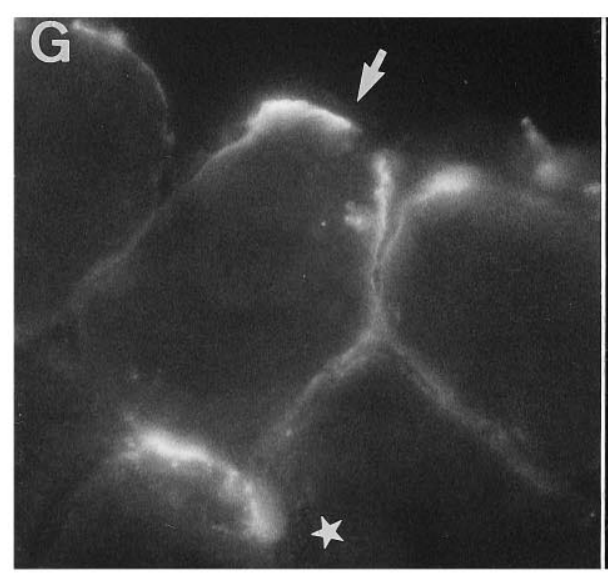
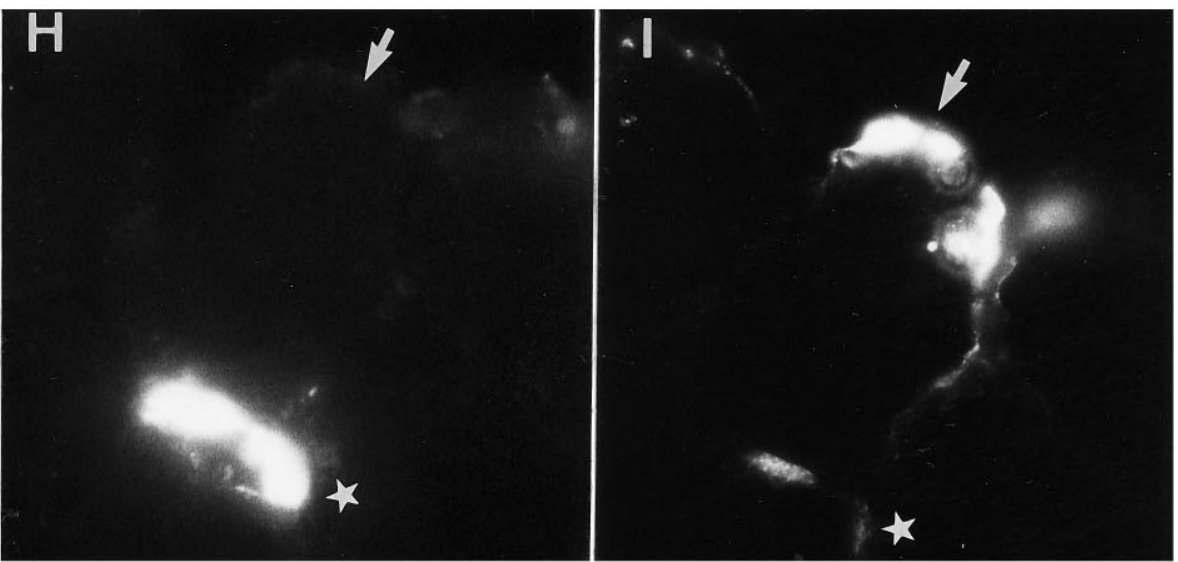

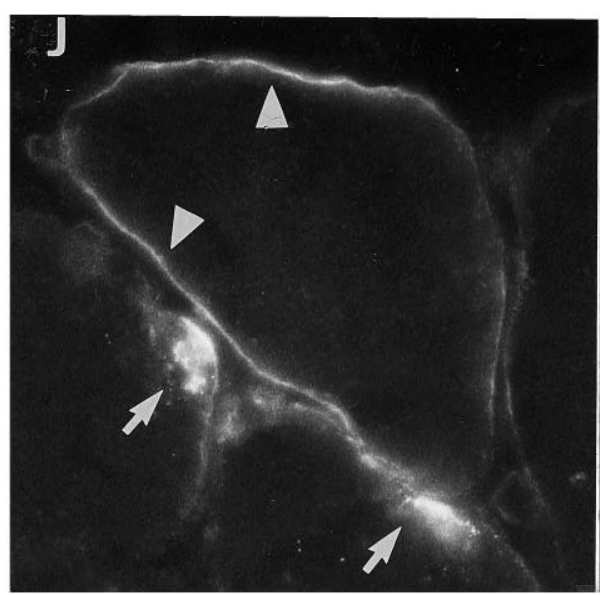

MuSK

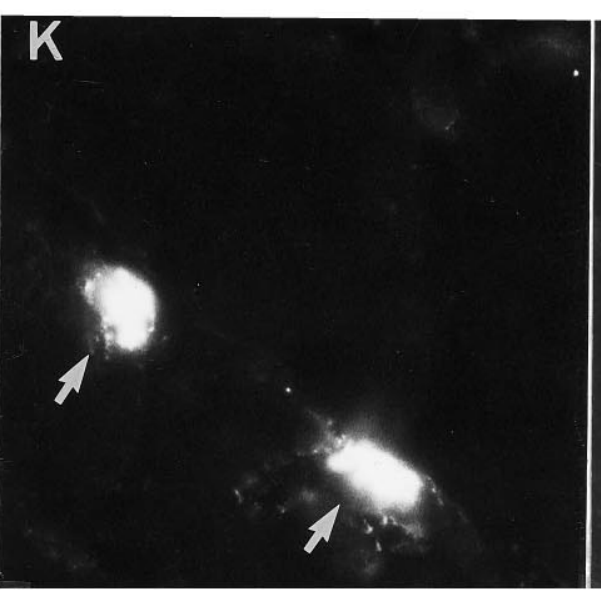

AChR

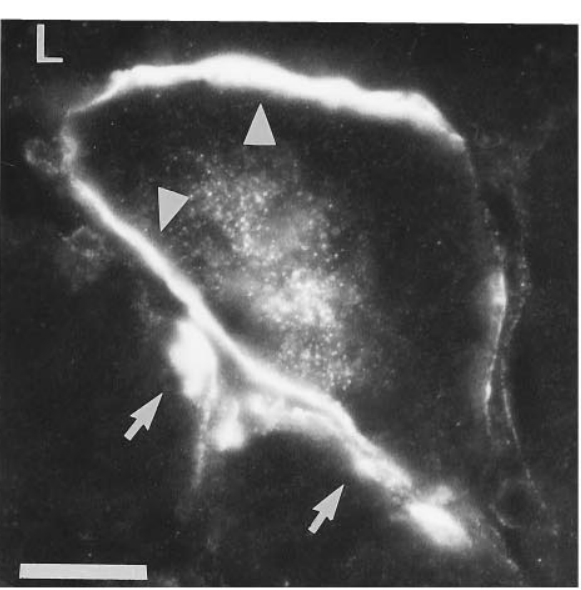

Agrin

\section{ectopic Agrin}

Figure 4. Accumulation of MuSK at original endplates $(A-D)$ and at agrin-induced ectopic AChR clusters $(E-L)$. Antibodies produced against Nsk2, the mouse homolog of MuSK, but not preimmune serum (Pre-IS), stained original endplates identified with Rh- $\alpha \mathrm{BGT}(A-D)$. E-F, $G-I, J-L$, Three examples of ectopic MuSK accumulation. $E-F$, Agrin-induced ectopic MuSK-aggregates (E, arrow) do not induce AChR aggregates along their entire length. Triple-staining protocols revealed that extrasynaptic MuSK $(G, J)$ more closely followed the distribution of ectopically expressed chick agrin $(I$, $L$ ) than AChR aggregates $(H, K)$. G-I, Arrows show sites at which expression of both cAgrin ${ }_{7 \mathrm{~A} 4 \mathrm{~B} 8}$ and MuSK is not associated with AChR clusters, whereas another site in a neighboring muscle fiber contained AChRs (stars). $J-L$, AChR aggregates are located at sites with elevated expression of MuSK and chick agrin (arrows). In a neighboring myofiber a reduced level of MuSK staining matches the distribution of chick agrin (arrowheads) but is not colocalized with AChRs. Note that intracellular labeling for chick agrin $(L)$ indicates that this muscle fiber was injected with the agrin expression construct. Scale bars: in $A-F, 35 \mu \mathrm{m}$; in $G-L, 50 \mu \mathrm{m}$. 


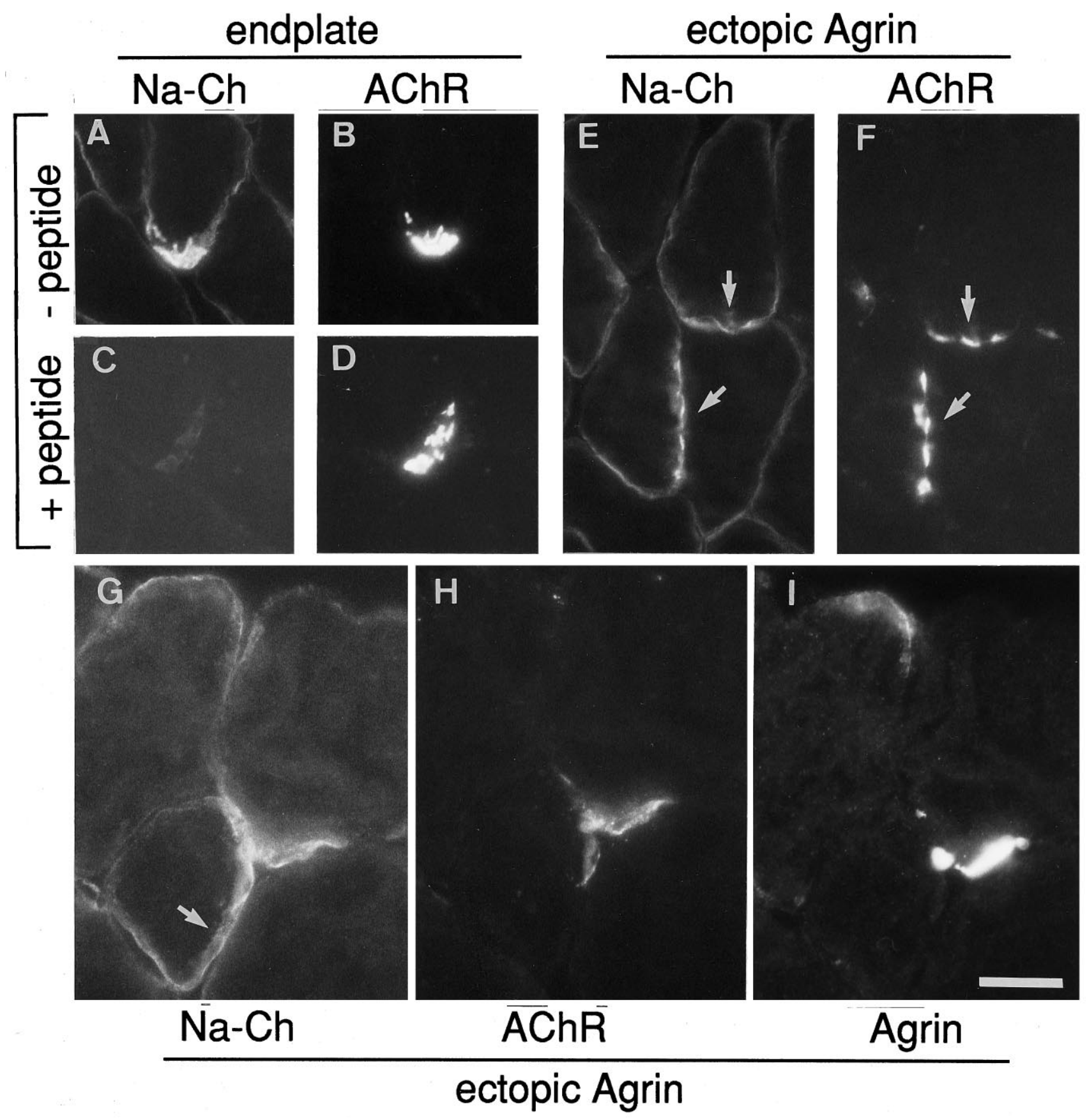

Figure 5. Voltage-gated $\mathrm{Na}^{+}$channels $(\mathrm{Na}-\mathrm{Ch})$ are aggregated at extrasynaptic regions by expression of neural chick agrin. Antisera specific for Na ${ }^{+}$ channels specifically labeled endplates $(A, B)$. Preabsorption with immunogenic peptide $(C)$ inhibits the staining at endplates $(D)$. The distribution of $\mathrm{Na}^{+}$channel immunoreactivity is shown for two extrasynaptic sites of muscle fibers injected with agrin expression plasmids $(E, F, G-I)$. The general outline of $\mathrm{Na}^{+}$channel immunoreactivity $\left(E\right.$, arrows) follows ectopic AChR aggregates $\left(F\right.$, arrows). In some cases, however, the distribution of Na ${ }^{+}$ channels $(G$, arrow) was not confined to the site of extrasynaptic AChRs $(H)$ induced by agrin $(I)$. Scale bars: in $A-F, 35 \mu \mathrm{m}$; in $G-I, 50 \mu \mathrm{m}$.

al., 1993; Chu et al., 1995). Both neuregulins and ErbBs are concentrated at the NMJ (Altiok et al., 1995; Goodearl et al., 1995; Jo et al., 1995; Moscoso et al., 1995; Sandrock et al., 1995). However, ectopic agrin alone can induce the synthesis and aggregation of functional adult subtype AChR channels (Jones et al., 1996, 1997). One way in which agrin might induce AChR gene transcription via the neuregulin/ErbB pathway is by inducing the binding of a muscle-derived neuregulin to synaptic BL and by concentrating ErbB receptors in synaptic muscle membrane. Therefore, we stained sections containing ectopic agrin with antibodies for ErbB2 and ErbB3. Indeed, both receptors could be observed readily at agrin-induced ectopic AChR clusters (Fig. 7), but staining intensity appeared weaker than at denervated endplates (data not shown). The lower staining intensity at agrininjected sites could be attributable to a lower level of ErbB accumulation by the ectopic agrin than by the nerve or to ErbB immunoreactivity associated with perisynaptic cells present at the denervated endplates. To distinguish between these possibilities, we destroyed denervated soleus muscle, including perisynaptic cells, and allowed regeneration of new fibers inside their old BL 

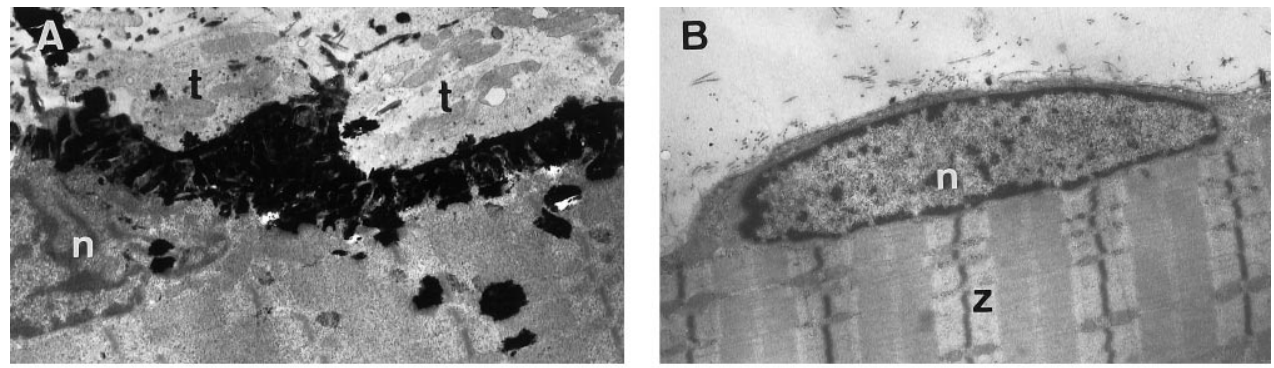

Figure 6. Ultrastructure of postsynaptic specializations induced by ectopic expression of agrin in rat soleus muscle. Before being processed for electron microscopy, muscle injected with agrin cDNA expression constructs was sectioned longitudinally and stained for cholinesterase activity. $A$, Normal endplate in injected muscle shown as control. Note polymorphic nucleus $(n)$ next to heavily stained synaptic folds and adjacent nerve terminal $(t) . B, \mathrm{~A}$ normal extrasynaptic muscle fiber nucleus $(n)$ is lens-shaped and tightly fits in between smooth sarcolemma and myofibrils; $z$, Z-band of myofibrils. $C$, A region expressing ectopic agrin is characterized by deep, cholinesterase-positive membrane folds and underlying polymorphic nuclei. $D$, Higher magnification of the region boxed in $C$ showing sarcolemmal invaginations, which contain basal lamina (arrows). Scale bars: in $A-C, 1.9 \mu \mathrm{m}$; in $D, 0.5 \mu \mathrm{m}$.
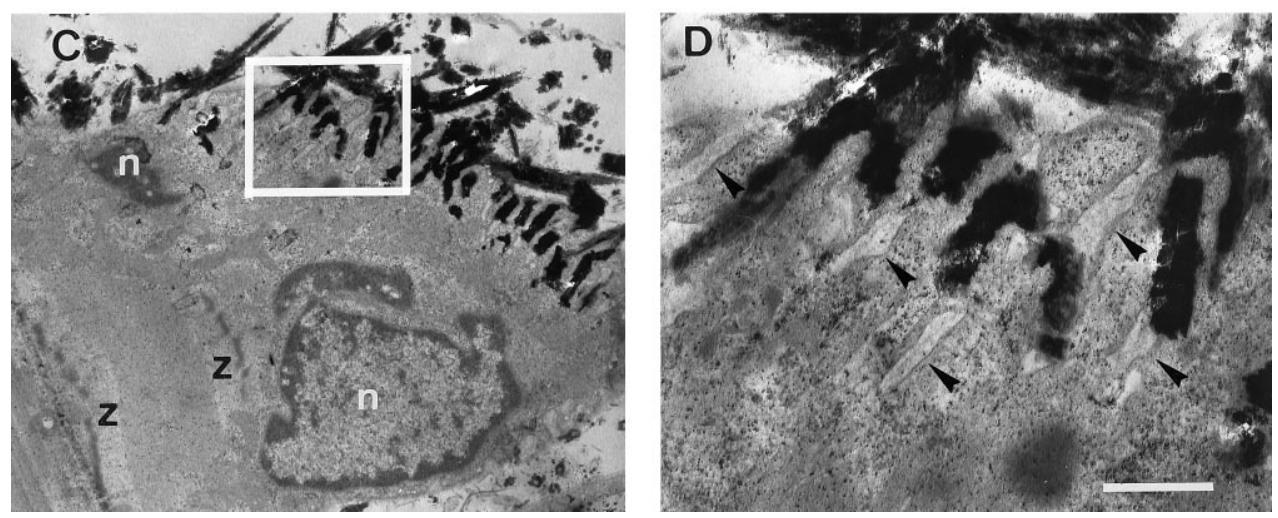

sheaths in the absence of nerve. Under the regulation of neural factors associated with the old synaptic BL, such fibers form new functional endplates (Brenner et al., 1992; Jo et al., 1992) that include a high concentration of ErbBs (Zhu et al., 1995). Two to three weeks after muscle damage, ErbB2 and ErbB3 were observed at such sites, and the staining intensity was similar to ectopic agrin-induced sites (data not shown).

Taken together, these experiments demonstrate that an agrin isoform that normally is expressed by motor neurons is sufficient to induce the differentiation of a postsynaptic apparatus, the morphology of which closely resembles that of mature endplates.

\section{Induction of postsynaptic specializations in vivo is splice-dependent}

On cultured myotubes AChR aggregation induced by bathapplied agrin is observed only with agrin isoforms containing amino acid inserts at splice sites A and B (for review, see Bowe and Fallon, 1995). However, when presented in a cell-attached form, rat agrin lacking inserts at sites $\mathrm{A}$ and $\mathrm{B}$ was shown to have some AChR-aggregating activity (Campanelli et al., 1991; Ferns et al., 1992, 1993). To address whether the agrin ${ }_{\text {Аово }}$ isoform, when expressed in a physiological context, would have such aggregating activity, we also injected cDNA constructs encoding

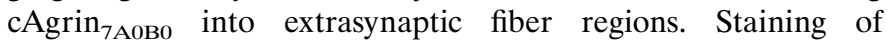
cAgrin $_{7 \mathrm{AOB} 0}$-expressing fibers with anti-chick agrin antibodies showed no obvious difference in expression levels to fibers expressing cAgrin $_{7 \mathrm{~A} 4 \mathrm{~B} 8}$ (Fig. 8), except that the robust deposits

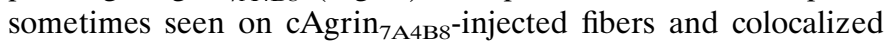
with AChR clusters were not observed. As documented before (see Fig. 1), cAgrin $_{7 \mathrm{~A} 4 \mathrm{~B} 8}$ deposited at the ectopic sites was more extended than the clusters of AChRs it induced (Fig. 8, arrow). Unlike in the $\mathrm{cAgrin}_{7 \mathrm{~A} 4 \mathrm{~B} 8}$-expressing and adjacent muscle fibers, where AChR clusters were always observed, AChR clusters were never detected after expression of cAgrin $_{7 \text { Аово }}$ neither in the injected nor in their neighboring fibers. Hence, the activity of agrin to induce AChR aggregation in vivo is strictly dependent on the presence of amino acid inserts at site A and/or site B.

\section{DISCUSSION}

The "agrin hypothesis" (McMahan, 1990) states that agrin synthesized by motor neurons and released at their endings is crucial for the differentiation of the subsynaptic apparatus in myofibers.

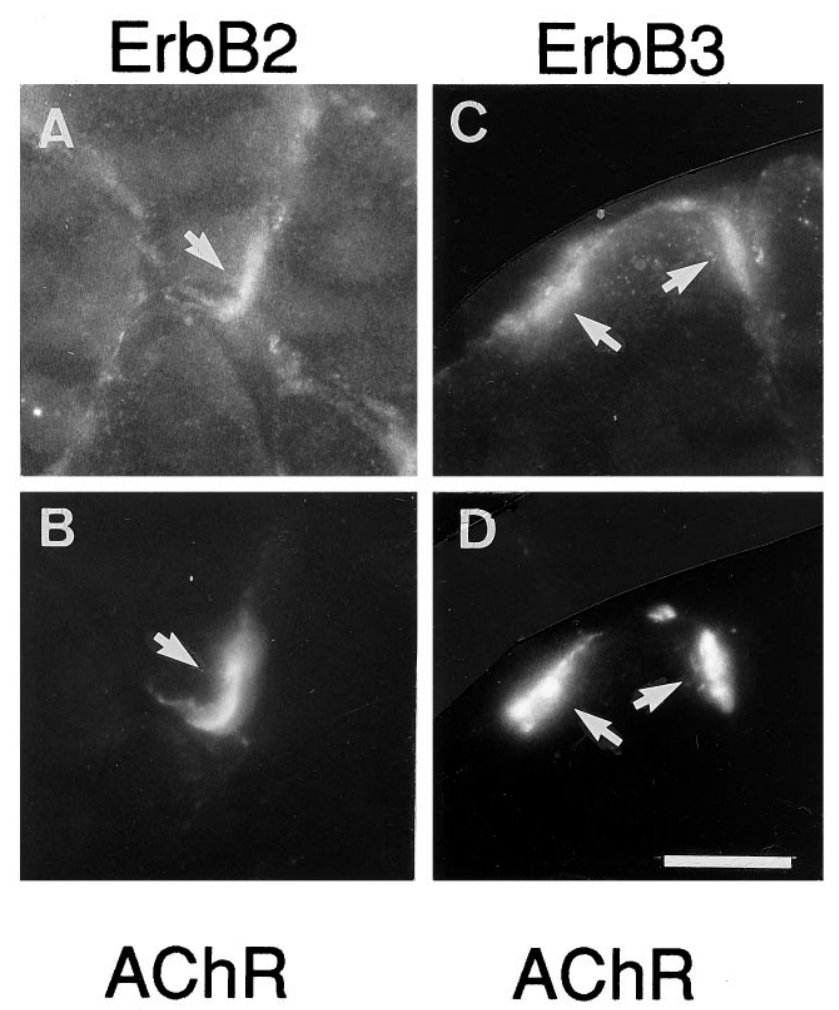

Figure 7. $\operatorname{ErbB} 2(A)$ and ErbB3 $(C)$ receptors are colocalized with cAgrin $_{7 \mathrm{~A} 4 \mathrm{~B} 8}$-induced $\mathrm{AChR}$ aggregates $(B, D)$ at extrasynaptic regions of innervated rat muscle fibers. Shown is labeling of sections with specific antibodies and Rh- $\alpha$ BGT $(B, D)$. Scale bar, $50 \mu \mathrm{m}$. 

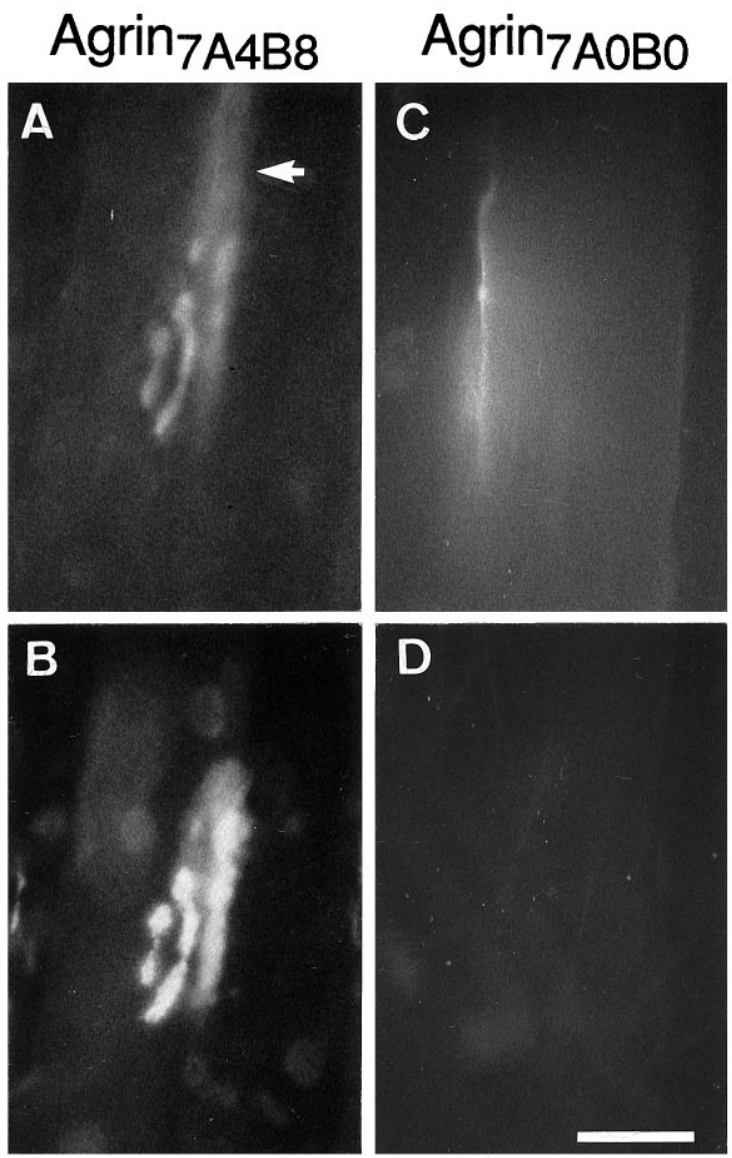

AChR

AChR

Figure 8. The induction of ectopic synapse-like specializations by agrin depends on the presence of amino acid inserts at the A and B splice sites. Shown are en face views of superficial rat soleus muscle fibers stained for agrin and AChRs after injection of $\operatorname{cAgrin}_{7 \mathrm{~A} 4 \mathrm{~B} 8}(A, B)$ and $\mathrm{cAgrin}_{7 \mathrm{~A} 0 \mathrm{~B} 0}$ $(C, D)$ expression plasmids, respectively. Live muscle was stained for ectopically expressed agrin $(A, C)$ and AChRs $(B, D)$. Expression of cAgrin $_{7 \mathrm{~A} 4 \mathrm{~B} 8}$, but not $\mathrm{cAgrin}_{7 \mathrm{~A} 0 \mathrm{~B} 0}$, induces the expression of ectopic AChR aggregates. Note that the distribution of agrin ${ }_{7 \mathrm{~A} 4 \mathrm{~B} 8}$ labeling exceeds the distribution of ectopic AChRs (arrow in $A$ ). Scale bar, $50 \mu \mathrm{m}$.

When added to cultured myotubes that express AChRs constitutively, agrin triggers the redistribution of surface AChRs in myotube membranes to form AChR aggregates. Colocalized with these are components seen also at the normal postsynaptic specializations and thought to be involved in their stabilization (see references in the introductory remarks). The potential of agrin to induce AChR clusters in electrically active muscle in vivo where AChR expression is suppressed (Lømo and Rosenthal, 1972; Goldman et al., 1988; Kues et al., 1995) has not been investigated.

To assess the role of agrin as the neural mediator of postsynaptic differentiation in vivo, we have induced the local expression of full-length agrin at extrasynaptic regions of innervated muscle fibers. The agrin ${ }_{\mathrm{A} 4 \mathrm{~B} 8}$ isoform used in this study is abundantly expressed by chick and rat motor neurons (Hoch et al., 1993; Smith and O'Dowd, 1994; Ma et al., 1994; Stone and Nikolics, 1995). Our experiments demonstrate that ectopic neural agrin can induce ectopic AChR clusters in vivo. The origin of the stronger deposits of agrin often seen within the extended region of agrin immunoreactivity and closely matching AChR clusters is not clear (see, for example, Fig. 8A). Because agrin attaches to laminin (Denzer et al., 1997) and laminin- $\beta 2$ is closely colocalized with AChR clusters, agrin may become bound preferentially at such sites. Our experiments further demonstrate that agrin alone can induce the differentiation of an ectopic postsynapticlike structure locally, containing molecular components of normal postsynaptic specializations. Because the fibers remained innervated at their original endplates during the entire experiment, the differentiation was activity-resistant. Combined with our previous results that ectopic agrin is sufficient to induce the functional elements of normal endplate membrane, i.e., clusters of adulttype AChR channels and AChE activity (Jones et al., 1997), the present data support our hypothesis that nerve-derived agrin acts as the key neural mediator for differentiation of functional subsynaptic specializations in electrically active muscle fibers.

\section{Distribution of MuSK at sites of ectopic AChR aggregation}

It has been demonstrated recently that agrin-induced $\mathrm{AChR}$ clustering requires MuSK, a muscle-specific protein tyrosine kinase that might be part of the agrin receptor complex (DeChiara et al., 1996; Glass et al., 1996). Moreover, recent findings show that MuSK accumulates at nerve-muscle contacts even in rapsyndeficient mice (Apel et al., 1997). Nevertheless, AChRs are not accumulated at the nerve-muscle contacts in the rapsyn-deficient mice (Gautam et al., 1995). These results strongly suggest that motor neurons induce the formation of a primary MuSKcontaining scaffold and that the formation of this scaffold is rapsyn-independent, whereas the aggregation of AChRs is rapsyn-dependent. We now have found that, as with normal endplates, myofiber regions that express cAgrin 7A4B8 $_{3}$ showed accumulation of MuSK at sites of agrin deposition. These results show that neural agrin alone is sufficient to localize MuSK to specific sites and they suggest that accumulation of MuSK at nerve-muscle contacts may be induced by neural agrin. Our results that the colocalization of agrin and MuSK does not necessarily codistribute with AChRs, rapsyn, or utrophin also support the conclusion of Apel et al. (1997) that localization of MuSK does not require rapsyn. In addition, our results suggest that MuSK aggregation does not suffice to stabilize AChR aggregates. Accumulation of AChRs may depend on additional factors, which may be limited in abundance. Such limitation might restrict the growth of the AChR cluster-analogous to the perisynaptic regions of denervated fibers, which do not accept innervation by a transplanted foreign nerve (Lømo et al., 1984).

\section{Accumulation of $\mathrm{Na}^{+}$channels and the formation of ectopic junctional membrane folds}

At the normal neuromuscular synapse, $\mathrm{Na}^{+}$channels are located in the depth of the secondary synaptic folds (Flucher and Daniels, 1989), i.e., spatially separate from the AChR clusters, utrophin, and rapsyn (Bewick et al., 1992), which are localized at the crests of folds. They also are anchored to the cytoskeleton by an apparently distinct mechanism involving ankyrin (Srinivasan, 1988; Flucher and Daniels, 1989). In the present experiments with ectopic cAgrin ${ }_{7 \mathrm{~A} 4 \mathrm{~B} 8}$, aggregates of voltage-gated $\mathrm{Na}^{+}$channels were not always colocalized closely with AChR clusters, but they were observed exclusively at or near agrin-induced AChR aggregates. This is in agreement with earlier observations showing that immobilized, but not soluble, agrin induces $\mathrm{Na}^{+}$channel aggregates on cultured myofibers (Lupa and Caldwell, 1991; Sharp and Caldwell, 1996). The dependence of $\mathrm{Na}^{+}$channel aggregation on agrin immobilization also may explain apparently conflicting re- 
sults by Corfas and Fischbach (1993) that $\mathrm{Na}^{+}$channels in cultured chick myotubes are induced by ARIA/heregulin, but not by soluble agrin. As proposed here and previously (Jones et al., 1996, 1997) for agrin-induced AChR gene expression, agrin attached to BL may stimulate the muscle fiber to secrete neuregulin and/or modify the BL in such a way as to provide binding sites for muscle-derived NRG. Such NRG aggregates would, in turn, induce the ectopic $\mathrm{Na}^{+}$channel aggregates.

\section{Formation of endplate membrane in electrically active fibers?}

The formation of ectopic endplate structures by neural agrin in innervated muscle fibers is striking, because adult muscle fibers, if innervated, will not accept innervation by a foreign nerve (Jansen et al., 1973). The reason for the "resistance" to hyperinnervation seems to be electrical muscle activity, because muscles paralyzed by a blockade of impulse conduction in the original nerve do accept hyperinnervation by a foreign nerve (Cangiano et al., 1980). Indeed, signals acting from electrically inactive muscle (Rassendren et al., 1992) on the nerve seem to play a key role in the sprouting of motor axons in partially denervated muscle, and innervation can be prevented if the denervated muscle is kept active by chronic stimulation (Jansen et al., 1973). These observations, together with the apparent absence of MuSK from extrasynaptic regions of innervated muscle (Valenzuela et al., 1995), raise the question of how in our experiments ectopic agrin could have induced postsynaptic differentiation on active, innervated fibers. The possibility of fiber damage and degeneration on plasmid injection, potentially resulting in susceptibility to innervation, was excluded in control experiments (our unpublished data). Nevertheless, it remains possible that the muscle was transiently receptive to innervation and MuSK was upregulated as a consequence of tissue manipulation during muscle exposure for plasmid injection. Another possibility is that, even in innervated muscle, some MuSK might be expressed in nonsynaptic segments, as suggested by low levels of MuSK mRNA detected in extrasynaptic regions of normal rat soleus muscle (our unpublished data). Extrasynaptic MuSK then may become "trapped" by the neural agrin deposited at ectopic sites of agrin-secreting fibers, causing the formation of a primary MuSK-based scaffold. Therefore, our finding that, in innervated muscle, agrin alone could form ectopic synaptic membrane is consistent with the notion that secretion of agrin from the terminals of transplanted foreign motor axons may depend entirely on (inductive or permissive) signals supplied by inactive muscle only. In the present experiments agrin was supplied irrespective of muscle activity, consistent with the idea that active muscle per se can accept innervation if it is supplied with the appropriate neural factor(s). The present experiments suggest that, for synaptic differentiation of the muscle fiber, this factor is agrin. For motor nerve terminal differentiation, it again may be agrin, because in immobilized form agrin provides stop and differentiation signals for outgrowing motor neurites in vitro (Campagna et al., 1995).

\section{REFERENCES}

Altiok N, Bessereau JL, Changeux JP (1995) ErbB3 and erbB2/neu mediate the effect of heregulin on acetylcholine receptor gene expression in muscle: differential expression at the endplate. EMBO J 14:4258-4266.

Apel ED, Merlie JP (1995) Assembly of the postsynaptic apparatus. Curr Opin Neurobiol 5:62-67.

Apel ED, Roberds SL, Campbell KP, Merlie JP (1995) Rapsyn may function as a link between the acetylcholine receptor and the agrinbinding dystrophin-associated glycoprotein complex. Neuron 15:115-126.

Apel ED, Glass DJ, Moscoso LM, Yancopoulos GD, Sanes JR (1997) Rapsyn is required for MuSK signaling and recruits synaptic components to a MuSK-containing scaffold. Neuron 18:623-635.

Bewick GS, Louise VB, Nicholson B, Young C, O'Donnell E, Slater CR (1992) Different distribution of dystrophin and related proteins at nerve-muscle junctions. NeuroReport 3:857-860.

Bowe MA, Fallon JR (1995) The role of agrin in synapse formation. Annu Rev Neurosci 18:443-462.

Bowe MA, Deyst KA, Leszyk JD, Fallon JR (1994) Identification and purification of an agrin receptor from Torpedo postsynaptic membranes: a heteromeric complex related to the dystroglycans. Neuron 12:1173-1180.

Brenner HR, Witzemann V, Sakmann B (1990) Imprinting of acetylcholine receptor mRNA accumulation in mammalian neuromuscular synapses. Nature 344:544-547.

Brenner HR, Herczeg A, Slater CR (1992) Synapse-specific expression of acetylcholine receptor genes and their products at original synaptic sites in rat soleus muscle fibers regenerating in the absence of innervation. Development 116:41-53.

Campagna JA, Ruegg MA, Bixby JL (1995) Agrin is a differentiationinducing "stop signal" for motoneurons in vitro. Neuron 15:1365-1374.

Campanelli J, Hoch W, Rupp F, Kreiner T, Scheller RH (1991) Agrin mediates cell contact-induced acetylcholine receptor clustering. Cell 67:909-916.

Campanelli JT, Roberds SL, Campbell KP, Scheller RH (1994) A role for dystrophin-associated glycoproteins and utrophin in agrin-induced AChR clustering. Cell 77:663-674.

Cangiano A, Lømo T, Lutzemberger L, Sveen O (1980) Effects of chronic nerve conduction on formation of neuromuscular junction and junctional AChE in the rat. Acta Physiol Scand 109:283-296.

Carbonetto S, Lindenbaum M (1995) The basement membrane at the neuromuscular junction: a synaptic mediatrix. Curr Opin Neurobiol 5:596-605.

Chu GC, Moscoso LM, Sliwkowski MX, Merlie JP (1995) Regulation of the acetylcholine receptor $\epsilon$-subunit gene by recombinant ARIA: an in vitro model for transynaptic gene regulation. Neuron 14:329-339.

Corfas G, Fischbach GD (1993) The number of $\mathrm{Na}^{+}$channels in cultured chick muscle is increased by ARIA, an acetylcholine receptorinducing activity. J Neurosci 13:2118-2125.

Cullen BR (1987) Use of eukaryotic expression technology in the functional analysis of cloned genes. Methods Enzymol 152:628-704.

DeChiara TM, Bowen DC, Valenzuela DM, Simmons MV, Poueymirou WT, Thomas S, Kinetz E, Compton DL, Rojas E, Park JS, Smith C, DiStefano PS, Glass DJ, Burden SJ, Yancopoulos GD (1996) The receptor tyrosine kinase MuSK is required for neuromuscular junction formation in vivo. Cell 85:501-512.

Denzer AJ, Gesemann M, Schumacher B, Ruegg MA (1995) An aminoterminal extension is required for the secretion of chick agrin and its binding to extracellular matrix. J Cell Biol 131:1547-1560.

Denzer AJ, Brandenberger R, Gesemann M, Chiquet M, Ruegg MA (1997) Agrin binds to the nerve-muscle basal lamina via laminin. J Cell Biol 137:671-683.

Dugandzija-Novakovic S, Koszowski AG, Levinson SR, Shrager P (1995) Clustering of $\mathrm{Na}^{+}$channels and node of Ranvier formation in remyelinating axons. J Neurosci 15:492-503.

Fallon JR, Hall ZW (1994) Building synapses: agrin and dystroglycan stick together. Trends Neurosci 17:469-473.

Falls DL, Rosen KM, Corfas G, Lane WS, Fischbach GD (1993) ARIA, a protein that stimulates acetylcholine receptor synthesis, is a member of the Neu ligand family. Cell 72:801-815.

Ferns MJ, Hoch W, Campanelli JT, Rupp F, Hall ZW, Scheller RH (1992) RNA splicing regulates agrin-mediated acetylcholine receptor clustering activity on cultured myotubes. Neuron 8:1079-1086.

Ferns MJ, Campanelli JT, Hoch W, Scheller RH, Hall ZW (1993) The ability of agrin to cluster AChRs depends on alternative splicing and on cell surface proteoglycans. Neuron 11:491-502.

Flucher BE, Daniels MP (1989) Distribution of $\mathrm{Na}^{+}$channels and ankyrin in neuromuscular junctions is complementary to that of acetylcholine receptors and the $43 \mathrm{kd}$ protein. Neuron 3:163-175.

Frail DE, McLaughlin LL, Mudd J, Merlie JP (1988) Identification of the mouse muscle 43,000-dalton acetylcholine receptor-associated protein (RAPsyn) by cDNA cloning. J Biol Chem 263:15602-15607. 
Froehner SC (1984) Peripheral proteins of postsynaptic membranes from Torpedo electric organ identified with monoclonal antibodies. J Cell Biol 99:88-96.

Ganju P, Walls E, Brennan J, Reith AD (1995) Cloning and developmental expression of Nsk2, a novel receptor tyrosine kinase implicated in skeletal myogenesis. Oncogene 11:281-290.

Gautam M, Noakes PG, Mudd J, Nichol M, Chu GC, Sanes JR, Merlie JP (1995) Failure of postsynaptic specialization to develop at neuromuscular junctions of rapsyn-deficient mice. Nature 377:232-236.

Gautam M, Noakes PG, Moscoso L, Rupp F, Scheller RH, Merlie JP, Sanes JR (1996) Defective neuromuscular synaptogenesis in agrindeficient mice. Cell 85:525-535.

Gee SH, Montanaro F, Lindenbaum MH, Carbonetto S (1994) Dystroglycan- $\alpha$, a dystrophin-associated glycoprotein, is a functional agrin receptor. Cell 77:675-686.

Gesemann M, Denzer AJ, Ruegg MA (1995) Acetylcholine receptoraggregating activity of agrin isoforms and mapping of the active site. J Cell Biol 128:625-636.

Gesemann M, Cavalli V, Denzer AJ, Brancaccio A, Schumacher B, Ruegg MA (1996) Alternative splicing of agrin alters its binding to heparin, dystroglycan, and the putative agrin receptor. Neuron 16:755-767.

Glass DJ, Bowen DC, Stitt TN, Radziejewski C, Bruno J, Ryan TE, Gies DR, Shah S, Mattsson K, Burden SJ, DiStefano PS, Valenzuela DM, DeChiara TM, Yancopoulos GD (1996) Agrin acts via a MuSK receptor complex. Cell 85:1-20.

Gluzman Y (1981) SV40-transformed simian cells support the replication of early SV40 mutants. Cell 23:175-182.

Goldman D, Brenner HR, Heinemann S (1988) Acetylcholine receptor $\alpha-, \beta-, \gamma-$, and $\delta$-subunit mRNA levels are regulated by muscle activity. Neuron 1:329-333.

Goodearl ADJ, Yee AG, Sandrock Jr AW, Corfas G, Fischbach GD (1995) ARIA is concentrated in the synaptic basal lamina of the developing chick neuromuscular junction. J Cell Biol 130:1423-1434.

Gorman CM, Gies DR, McCray G (1990) Transient production of proteins using an adenovirus transformed cell line. DNA Protein Eng Tech 2:3-10.

Henry MD, Campbell KP (1996) Dystroglycan: an extracellular matrix receptor linked to the cytoskeleton. Curr Opin Cell Biol 8:625-631.

Herczeg A, Jones G, Brenner HR (1995) Involvement of extracellular matrix in acetylcholine receptor $\epsilon$-subunit gene expression at the rat neuromuscular junction. Neurosci Lett 193:33-36.

Hoch W, Ferns M, Campanelli JT, Hall ZW, Scheller RH (1993) Developmental regulation of highly spliced forms of agrin. Neuron 11:479-490.

Hoch W, Campanelli JT, Harrison S, Scheller RH (1994) Structural domains of agrin required for clustering of nicotinic acetylcholine receptors. EMBO J 13:2814-2821.

Hunter DD, Shah V, Merlie JP, Sanes JR (1989) A laminin-like adhesive protein concentrated in the synaptic cleft of the neuromuscular junction. Nature 338:229-234.

Ibraghimov-Beskrovnaya O, Ervasti JM, Leveille CJ, Slaughter CA, Sernett SW, Campbell KP (1992) Primary structure of dystrophinassociated glycoproteins linking dystrophin to the extracellular matrix. Nature 355:696-702.

Jansen JKS, Lømo T, Nicolaysen K, Westgaard RH (1973) Hyperinnervation of skeletal muscle fibers: dependence on muscle activity. Science 181:559-561.

Jennings CGB, Dyer SM, Burden SJ (1993) Muscle-specific trk-related receptor with a kringle domain defines a distinct class of receptor tyrosine kinases. Proc Natl Acad Sci USA 90:2895-2899.

Jo SA, Burden SJ (1992) Synaptic basal lamina contains a signal for synapse-specific transcription. Development 115:673-680.

Jo SA, Zhu X, Marchionni MA, Burden SJ (1995) Neuregulins are concentrated at nerve-muscle synapses and activate ACh receptor gene expression. Nature 373:158-161.

Jones G, Herczeg A, Ruegg MA, Lichtsteiner M, Kröger S, Brenner HR (1996) Substrate-bound agrin induces expression of acetylcholine receptor $\epsilon$-subunit in cultured mammalian muscle cells. Proc Natl Acad Sci USA 93:5985-5990.

Jones G, Meier T, Lichtsteiner M, Witzemann V, Sakmann B, Brenner HR (1997) Induction by agrin of ectopic and functional postsynapticlike membrane in innervated muscle. Proc Natl Acad Sci USA 94:2654-2659.
Koelle GB, Friedenwald JS (1949) A histochemical method for localizing cholinesterase activity. Proc Soc Exp Biol Med 70:617-622.

Kues WA, Brenner HR, Sakmann B, Witzemann V (1995) Local neurotrophic repression of gene transcripts encoding fetal AChRs at rat neuromuscular synapses. J Cell Biol 130:949-957.

Lømo T, Rosenthal J (1972) Control of ACh sensitivity by muscle activity in the rat. J Physiol (Lond) 221:493-513.

Lømo T, Mirsky R, Pockett S (1984) Formation of neuromuscular junctions in adult rats: role of postsynaptic impulse activity. In: Neuromuscular diseases (Serratrice G, Cros D, Desnuelle C, Gastaut J-L, Pellissier J-F, Pouget J, Schiauo A, eds), pp 393-399. New York: Raven.

Lowry OH, Rosenbrough NJ, Farr AL, Randall RJ (1951) Protein measurement with the folin phenol reagent. J Biol Chem 193:265-275.

Lupa MT, Caldwell JH (1991) Effect of agrin on the distribution of acetylcholine receptors and sodium channels on adult skeletal muscle fibers in culture. J Cell Biol 115:765-778.

Ma E, Morgan R, Godfrey EW (1994) Distribution of agrin mRNAs in the chick embryo nervous system. J Neurosci 14:2943-2952.

Martin PT, Sanes JR (1995) Role for a synapse-specific carbohydrate in agrin-induced clustering of acetylcholine receptors. Neuron 14:743-754.

Martinou JC, Falls DL, Fischbach GD, Merlie JP (1991) Acetylcholine receptor-inducing activity stimulates expression of the epsilon-subunit gene of the muscle acetylcholine receptor. Proc Natl Acad Sci USA 88:7669-7673.

McMahan UJ (1990) The agrin hypothesis. Cold Spring Harb Symp Quant Biol 55:407-418.

Meier T, Perez GM, Wallace BG (1995) Immobilization of nicotinic acetylcholine receptors in mouse $\mathrm{C} 2$ myotubes by agrin-induced protein tyrosine phosphorylation. J Cell Biol 131:441-451.

Meier T, Gesemann M, Cavalli V, Ruegg MA, Wallace BG (1996) AChR phosphorylation and aggregation induced by an agrin fragment that lacks the binding domain for $\alpha$-dystroglycan. EMBO J 15:2625-2631.

Morrisey JH (1981) Silver stains for proteins in polyacrylamide gels: a modified procedure with enhanced uniform sensitivity. Anal Biochem 117:307-310.

Moscoso LM, Chu GC, Gautam M, Noakes PG, Merlie JP, Sanes JR (1995) Synapse-associated expression of an acetylcholine receptorinducing protein, ARIA/heregulin, and its putative receptors, ErbB2 and ErbB3, in developing mammalian muscle. Dev Biol 172:158-169.

Ohlendieck K, Ervasti JM, Matsumura K, Kahl SD, Leveille C-J, Campbell KP (1991) Dystrophin-related protein is localized to neuromuscular junctions of adult skeletal muscle. Neuron 7:499-508.

Rassendren FA, Bloch-Gallego E, Tanaka H, Henderson CE (1992) Levels of mRNA coding for motoneuron growth-promoting factors are increased in denervated muscle. Proc Natl Acad Sci USA 89:7194-7198.

Reist NE, Magill C, McMahan UJ (1987) Agrin-like molecules at synaptic sites in normal, denervated, and damaged skeletal muscle. J Cell Biol 105:2457-2469.

Ruegg MA, Tsim KWK, Horton SE, Kröger S, Escher G, Gensch EM, McMahan UJ (1992) The agrin gene codes for a family of basal lamina proteins that differ in function and distribution. Neuron 8:691-699.

Rupp F, Ozcelik T, Linial M, Peterson K, Franke U, Scheller R (1992) Structure and chromosomal localization of the mammalian agrin gene. J Neurosci 12:3535-3544.

Sandrock AW, Goodearl ADJ, Yin Q-W, Chang D, Fischbach GD (1995) ARIA is concentrated in nerve terminals at neuromuscular junctions and at other synapses. J Neurosci 15:6124-6136.

Sanes JR, Engvall E, Butkowski R, Hunter DD (1990) Molecular heterogeneity of basal laminae: isoforms of laminin and collagen IV at the neuromuscular junction and elsewhere. J Cell Biol 111:1685-1699.

Sanes JR, Johnson YR, Kotzbauer PT, Mudd J, Hanley T, Martinou J-C, Merlie JP (1991) Selective expression of an acetylcholine receptorlacZ transgene in synaptic nuclei of adult muscle fibers. Development 113:1181-1191.

Sharp AA, Caldwell JH (1996) Aggregation of sodium channels induced by a postnatally upregulated isoform of agrin. J Neurosci 16:6775-6783.

Smith MA, O'Dowd DK (1994) Cell-specific regulation of agrin RNA splicing in the chick ciliary ganglion. Neuron 12:795-804.

Srinivasan Y, Elmer L, Davis J, Bennett V, Angelides K (1988) Ankyrin and spectrin associate with voltage-dependent sodium channels in brain. Nature 333:177-180.

Stone DM, Nikolics K (1995) Tissue- and agrin-specific expression pat- 
terns of alternatively spliced agrin mRNA transcripts in embryonic rat suggest novel developmental roles. J Neurosci 15:6767-6778.

Sugiyama J, Bowen DC, Hall ZW (1994) Dystroglycan binds nerve and muscle agrin. Neuron 13:103-115.

Tinsley JM, Blake DJ, Roche A, Fairbrother U, Riss J, Byth BC, Knight AE, Kendrick-Jones J, Suthers GK, Love DR, Edwards YH, Davies KE (1992) Primary structure of dystrophin-related protein. Nature 360:591-593.

Tinsley JM, Blake DJ, Zuellig RA, Davies KE (1994) Increasing complexity of the dystrophin-associated protein complex. Proc Natl Acad Sci USA 91:8307-8313.

Valenzuela DM, Stitt TM, DiStefano PS, Rojas E, Mattsson K, Compton DL, Nunez L, Park JS, Stark JL, Gies DR, Thomas S, LeBeau MM,
Fernald AA, Copeland NG, Jenkins NA, Burden SJ, Glass DJ, Yancopoulos GD (1995) Receptor tyrosine kinase specific for the skeletal muscle lineage: expression in embryonic muscle, at the neuromuscular junction, and after injury. Neuron 15:573-584.

Wallace BG (1989) Agrin-induced specializations contain cytoplasmic, membrane, and extracellular matrix-associated components of the postsynaptic apparatus. J Neurosci 9:1294-1302.

Wallace BG, Qu Z, Huganir RL (1991) Agrin induces phosphorylation of the nicotinic acetylcholine receptor. Neuron 6:869-878.

Zhu X, Lai C, Thomas S, Burden SJ (1995) Neuregulin receptors, erbB3 and erbB4, are localized at neuromuscular synapses. EMBO J 14:5 5842-5848. 